Full Paper

\title{
Fecal microbiota transplantation as a new treatment for canine inflammatory bowel disease
}

\author{
Ayaka NIINA ${ }^{1}$, Ryoko KIBE ${ }^{2}$, Ryohei SUZUKI' ${ }^{1}$, Yunosuke YUCHI ${ }^{1}$, Takahiro TESHIMA ${ }^{1}$, \\ Hirotaka MATSUMOTO ${ }^{1}$, Yasushi KATAOKA ${ }^{2}$ and Hidekazu KOYAMA ${ }^{1}$ \\ ${ }^{1}$ Laboratory of Veterinary Internal Medicine, School of Veterinary Medicine, Faculty of Veterinary Medicine, \\ Nippon Veterinary and Life Science University, 1-7-1 Kyonan-cho, Musashino-shi, Tokyo 180-8602, Japan \\ ${ }^{2}$ Laboratory of Veterinary Microbiology, School of Veterinary Medicine, Faculty of Veterinary Medicine, \\ Nippon Veterinary and Life Science University, 1-7-1 Kyonan-cho, Musashino-shi, Tokyo 180-8602, Japan
}

Received July 24, 2020; Accepted November 10, 2020; Published online in J-STAGE December 10, 2020

\begin{abstract}
In human medicine, fecal microbiota transplantation (FMT) is an effective treatment for recurrent Clostridioides difficile infection. It has also been tested as a treatment for multiple gastrointestinal diseases, including inflammatory bowel disease (IBD). However, only a few studies have focused on the changes in the microbiome following FMT for canine IBD. Here, we performed FMT in nine dogs with IBD using the fecal matter of healthy dogs and investigated the subsequent changes in the fecal microbiome and clinical signs. In three dogs, the fecal microbiome was examined by $16 \mathrm{~S}$ rRNA sequencing. Fusobacteria were observed at a low proportion in dogs with IBD. However, the post-FMT microbiome became diverse and showed a significant increase in Fusobacteria proportion. Fusobacterium was detected in the nine dogs by quantitative polymerase chain reaction. The proportion of Fusobacterium in the post-FMT fecal microbiome was significantly increased $(p<0.05)$. The changes in clinical signs (e.g., vomiting, diarrhea, and weight loss) were evaluated according to the canine inflammatory bowel disease activity index. The score of this index significantly decreased in all $\operatorname{dogs}(\mathbf{p}<0.05)$ with improvements in clinical signs. These improvements were related to the changes in the proportion of microbes, particularly the increase in Fusobacterium. The dogs with IBD showed a lower proportion of Fusobacterium than healthy dogs. This suggests that a low proportion of Fusobacterium is a characteristic feature of canine IBD and that Fusobacterium is involved in this disease. The results of this study may help elucidate the pathogenesis of this disease and its association with Fusobacterium.
\end{abstract}

Key words: inflammatory bowel disease, inflammatory bowel disease activity index, canine, fecal microbiota transplantation, microbiome, Fusobacterium

\section{INTRODUCTION}

The gene composition and functional properties of the whole gut microbiome have been evaluated using a recently developed enteric bacterium analytical procedure [1]. Studies have revealed an association between abnormalities in the gut microbiome (dysbiosis) and various diseases (e.g., metabolic disorders, autoimmune disease, and mental disorders) [1]. Therefore, fecal microbiota transplantation (FMT) is performed to improve the enteral environment in patients with these diseases. In the FMT procedure, fecal matter is collected from a tested donor, mixed with saline or another appropriate solution, strained to exclude particles (mostly hair and other solid particles), and administered to a patient by colonoscopy, endoscopy, sigmoidoscopy, or enema [2-4]. The infusion site varies with the administration route; for example, the injection site is the colon or cecum with colonoscopy, the duodenum with endoscopy, and the colon or rectum with enema. Several studies have reported that FMT is an effective treatment for recurrent Clostridioides difficile (formerly Clostridium difficile) infections [5-9]. The potential of FMT as a treatment for various diseases, such as inflammatory bowel disease (IBD), including ulcerative colitis, Crohn's disease, and irritable bowel syndrome, has been extensively investigated in recent years [6, 10-21].

Recently, FMT has been tested as a treatment for multiple gastrointestinal diseases in veterinary medicine [22]. Canine IBD is a common cause of idiopathic, chronic, and relapsing gastrointestinal (GI) diseases [23]. As a rule, dogs with IBD have been differentiated clinically from dogs with other chronic intestinal diseases (e.g., food-responsive- and antibiotic-

*Corresponding author. Ayaka Niina (E-mail: a.niina2173@gmail.com) 
responsive enteropathies) by performing a diagnostic treatment [23]. Endoscopy is a test for diagnosing IBD after excluding other chronic intestinal diseases [23]. The most common histological change associated with IBD is lymphocytic-plasmacytic inflammation; however, eosinophilic and neutrophilic inflammation can also occur [23]. The causes of IBD are unknown, but they are thought to be secondary to a complex interplay of genetics, immune dysregulation, and environmental factors, including the GI microbiome [24]. We previously reported the efficacy and safety of long-term FMT for canine IBD and demonstrated an association between improvements in clinical signs and changes in the fecal microbiome [25]. However, that study was conducted in just one dog; thus, the results needed to be confirmed in a larger number of cases. Here, we performed FMT in nine dogs with IBD to investigate the efficacy of this treatment for canine IBD.

\section{MATERIALS AND METHODS}

\section{Dogs with IBD and sample collection}

This study was conducted in nine dogs with clinical signs of chronic GI disease (e.g., vomiting, diarrhea, weight loss, hypoalbuminemia, and ascites); they were subjected to endoscopic examination in the medical center of Nippon Veterinary and Life Science University between 2016 and 2019. The profiles of these dogs are shown in Table 1. Inflammatory bowel disease was diagnosed based on histopathological evidence of lymphocyticplasmacytic enteritis after exclusion of food- and antibioticresponsive enteropathies [26]. Medication (e.g., antibiotics, antidiarrheal compounds, antiflatulents, corticosteroids, and cyclosporine) was discontinued 1 week before FMT. Feces samples collected from the dogs with IBD $6 \mathrm{hr}$ before FMT were used as the pre-FMT samples.

\section{Donor dog characteristics}

We collected fresh feces from five donor dogs. Physical and clinical examinations, complete blood count measurement, serum biochemical analysis, radiography, abdominal ultrasound, and fecal examination revealed that the donor dogs were in good health.

\section{Fecal microbiota transplant protocol}

The optimum dose and treatment interval for FMT procedures have not been established. We determined the optimum dose for FMT on the basis of similar ratios that proved to be successful in previous reports $[2,27]$.

Immediately after collection, approximately $3 \mathrm{~g} / \mathrm{kg}$ feces was dissolved in Ringer's solution. The slurry was then passed through sterilized gauze to filter out particulate matter. We administered $10 \mathrm{~mL} / \mathrm{kg}$ slurry to the dogs with IBD during each FMT procedure. Generally, FMT is performed either orally (e.g., nasoduodenal intubation and enteroscopy) or rectally (i.e., rectal enema and colonoscopy). We chose rectal enema as the route of administration for all dogs because of its efficacy and safety, as observed in our previous study [27]. In this study, we performed FMT one time after collection of the pre-FMT feces samples (on the same day). The symptoms improved and remained stable in all cases for 2 weeks. Feces samples collected by the dog owners 2 weeks after FMT were used as post-FMT samples. These were stored at $-80^{\circ} \mathrm{C}$ until investigation.
Table 1. Profiles of dogs with IBD used in this study

\begin{tabular}{rll}
\hline Age (years) & Sex & \multicolumn{1}{c}{ Breed } \\
\hline 10 & F, spyed & Miniature Dachshund \\
12 & M, neutered & Toy Poodle \\
12 & M, neutered & Cavalier King Charles Spaniel \\
12 & M, neutered & Toy Poodle \\
10 & M, neutered & Mix \\
7 & F, spyed & Border Collie \\
7 & M, neutered & Beagle \\
7 & M, neutered & Pomeranian \\
8 & F, spyed & Beagle \\
\hline
\end{tabular}

IBD: inflammatory bowel disease.

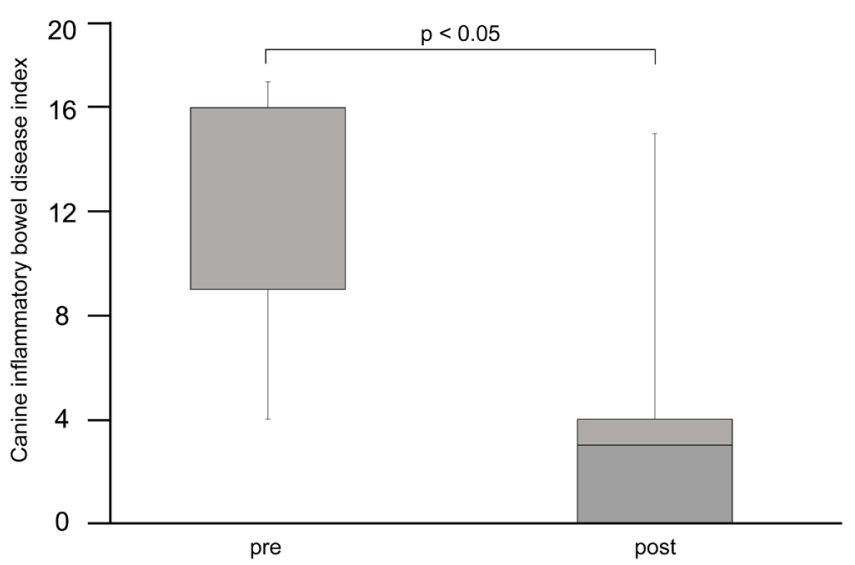

Fig. 1. Clinical observation according to the canine inflammatory bowel disease index (CIBDAI). The normal range is 3 or less. The post-fecal microbiota transplantation (FMT) CIBDAI score is significantly lower than the pre-FMT score $(\mathrm{p}<0.05)$. The data were analyzed using a t-test with R (version 2.8.1).

\section{Quantitative polymerase chain reaction (qPCR) analysis}

To exclude the occurrence of pathogenic microbe-related digestive system disease, a qPCR analysis (IDEXX Laboratories, Inc., Tokyo, Japan) of fecal samples from all dogs was performed. The dogs were found to be negative for Cryptosporidium spp., Giardia spp., Clostridium perfringens a toxin, C. difficile toxins A and B, Campylobacter jejuni, Campylobacter coli, Salmonella spp., canine parvovirus type 2, canine distemper virus, and canine enteric coronavirus.

\section{Evaluation of clinical signs}

We evaluated the pre- and post-FMT clinical signs of IBD according to the canine inflammatory bowel disease activity index (CIBDAI) (Fig. 1). The CIBDAI is based on six criteria, each scored on a scale of 0-3: attitude/activity, appetite, vomiting, stool consistency, stool frequency, and weight loss. The total composite scores are evaluated as follows: $0-3$, clinically insignificant; 4-5, mild; 6-8, moderate; 9 or higher, severe (Fig. 2) [27, 28]. After FMT, we requested that the owners of the dogs check the dogs' GI health.

\section{Fecal microbiome analysis}

A rarefaction analysis of the 16S rRNA sequence was performed at Anicom, Inc. (Tokyo, Japan) using the MiSeq Reporter software 


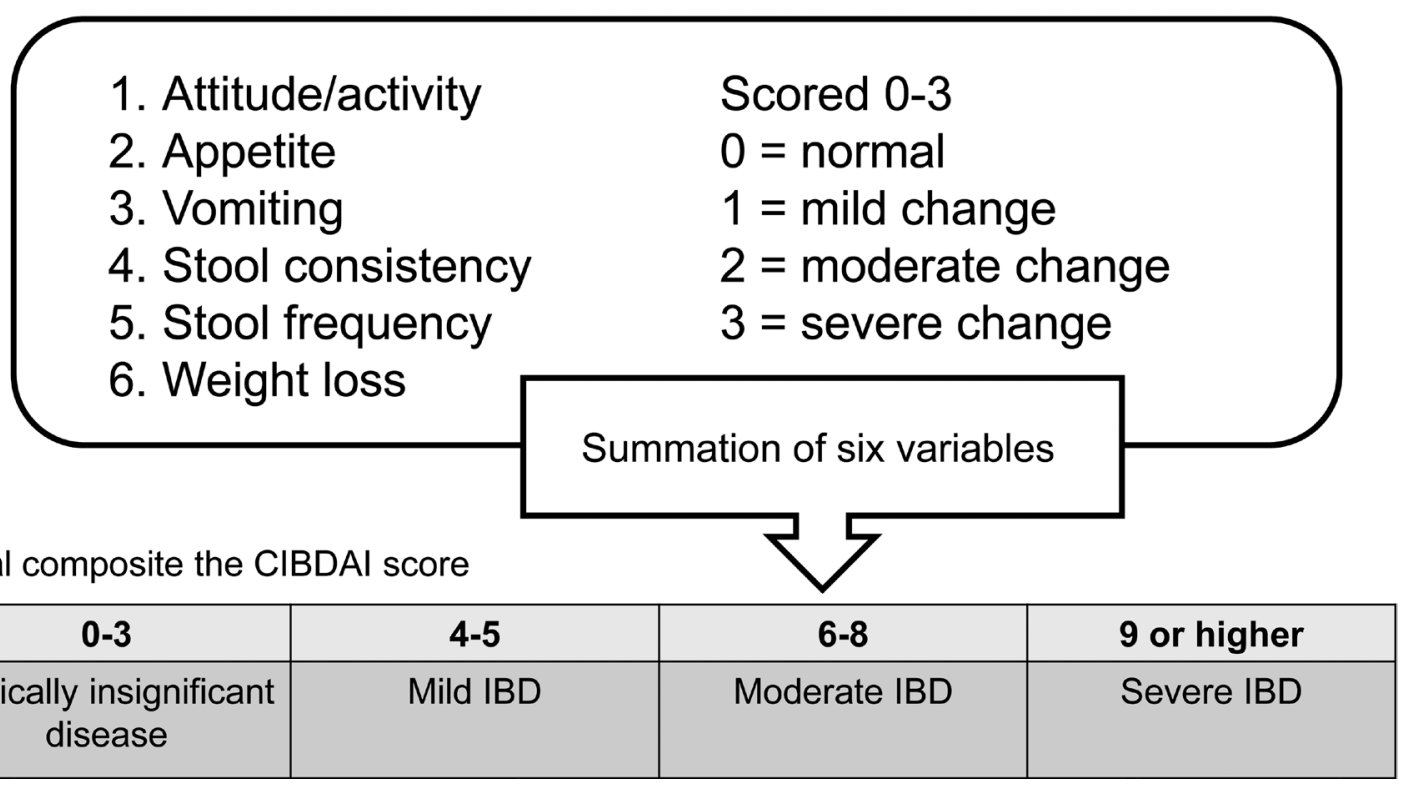

Fig. 2. Assessment of clinical signs using the canine inflammatory bowel disease index (CIBDAI). The CIBDAI is based on six criteria, each scored on a scale of 0-3: attitude/activity, appetite, vomiting, stool consistency, stool frequency, and weight loss. The total composite scores were evaluated as follows: $0-3$, clinically insignificant; $4-5$, mild; $6-8$, moderate; and 9 or higher, severe $[28,29]$.

(ver. 2.6.2.3, Illumina, Inc., San Diego, CA, USA) to investigate the fecal microbiome. Raw sequence data were screened, trimmed, and filtered with default settings using the QIIME 2 View tool. The analysis was performed on a randomly selected subset of 30,213 $\pm 4,721$ sequences from three dogs with IBD and three donor dogs. The V3-V4 16S rRNA sequence was analyzed to identify the bacterial groups Actinobacteria, Bacteroidetes, Firmicutes, Fusobacteria, Proteobacteria, Tenericutes, and others (Fig. 3A-C).

Because a considerable number of sequence results were obtained for Fusobacteria, we performed the qPCR analysis on all dogs to determine the number of Fusobacterium (Fig. 4). The oligonucleotide sequences of the primers and the respective annealing temperatures are summarized in Table $2[29,30]$.

\section{Fecal bacterial DNA extraction for $q P C R$}

DNA was extracted from each fecal sample (100 mg) using a genomic DNA isolation kit for stool samples (MachereyNagel GmbH \& Co. KG, Düren, Germany) according to the manufacturer's instructions. The qPCR assay was performed as reported previously $[29,30]$. The total extracted DNA was mixed with $100 \mu \mathrm{L}$ of TE buffer. The final reaction mix consisted of $10 \mu \mathrm{L}$ of Promega GoTaq ${ }^{\circledR}$ qPCR Master Mix (Promega, Madison, WI, USA), $0.4 \mu \mathrm{L}$ each of forward and reverse primers (final concentration: $4 \mathrm{pmol}$ ), $7.2 \mu \mathrm{L}$ of double-distilled water, and $2.0 \mu \mathrm{L}$ of normalized DNA (final concentration: $50 \mathrm{ng} / \mu \mathrm{L}$ ).

\section{Statistical analysis}

All statistical analyses were conducted using $\mathrm{R}$ (version 2.8.1). Clinical signs evaluated according to the CIBDAI were statistically analyzed using the t-test (all p-values $<0.05$ ). The Wilcoxon rank-sum test was used to examine the post-FMT changes in the number of Fusobacterium (all p-values $<0.05$ ).

\section{Ethics approval and informed consent}

This study was approved by the Ethical Committee of Nippon Veterinary and Life Science University (Permission number: 29-5).

\section{Consent for publication}

Written informed consent was obtained from the owners of the patient dogs for publication of this report.

\section{RESULTS}

\section{Clinical signs}

Improvements in the clinical signs were observed in all dogs at 3 days after FMT. The most common clinical sign was chronic diarrhea, followed by chronic vomiting. Some dogs with IBD that presented with chronic diarrhea and vomiting also showed weight loss. The post-FMT CIBDAI score was significantly lower in the dogs than the pre-FMT score $(\mathrm{p}<0.05)$ (Fig. 1). Additionally, no adverse effects were observed during FMT treatment in the dogs.

\section{Fecal microbiome analysis}

The rarefaction analysis of the V3-V4 16S rRNA sequence revealed changes between the proportions of the different bacteria in the pre-FMT feces compared with those in the post-FMT feces and in the donor fecal samples (Fig. 3A-C). The major bacterial phyla in the pre-FMT feces of the dogs with IBD were Firmicutes (51.7\%; Fig. 3A) and Proteobacteria (80.3\%, 52.2\%; Fig. 3B and $\mathrm{C})$. The proportions of Actinobacteria, Tenericutes, and Proteobacteria in the microbiome of the donor dogs were low, and the major bacterial phyla were Bacteroidetes, Firmicutes, and Fusobacteria. Generally, the proportion of Fusobacteria in the pre-FMT microbiome of the dogs with IBD was lower than that in the microbiome of the donor dogs and that in the post-FMT microbiome of the dogs with IBD.

The results of the qPCR analysis are shown in Fig. 4. The postFMT number of Fusobacterium was significantly higher than the 

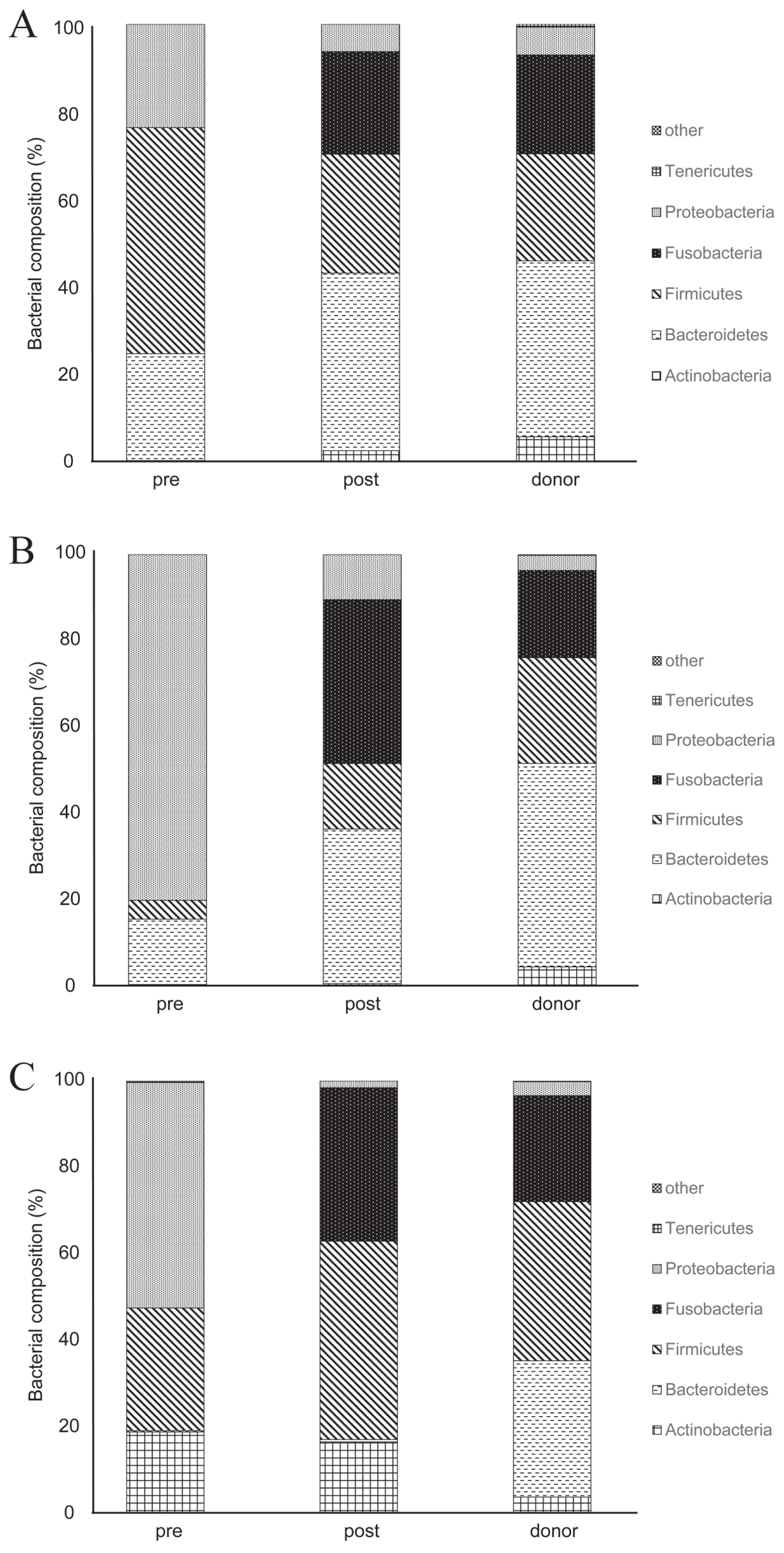

Fig. 3. Rarefaction analysis of the V3V4 16S rRNA sequence to determine the changes in the proportions of bacteria in the fecal samples of the dogs with inflammatory bowel disease (IBD) between before and after fecal microbiota transplantation (FMT) and to determine the proportions of bacteria in the fecal samples of the donor dogs. The phyla are shown in order from the top of the bar graph: other, Tenericutes, Proteobacteria, Fusobacteria, Firmicutes, Bacteroidetes, and Actinobacteria (Fig. 3A-C). The major bacterial phyla in the dogs with IBD were Firmicutes $(51.7 \%)$, as shown in Fig. 3A, and Proteobacteria (80.3\%, $52.2 \%$ ), as shown in Fig. $3 \mathrm{~B}$ and $\mathrm{C}$. The proportions of Actinobacteria, Tenericutes, and Proteobacteria in the microbiome of donor dogs were low, and the major bacterial phyla were Bacteroidetes, Firmicutes, and Fusobacteria. Generally, the proportion of Fusobacteria decreased in the microbiome of dogs with IBD. 


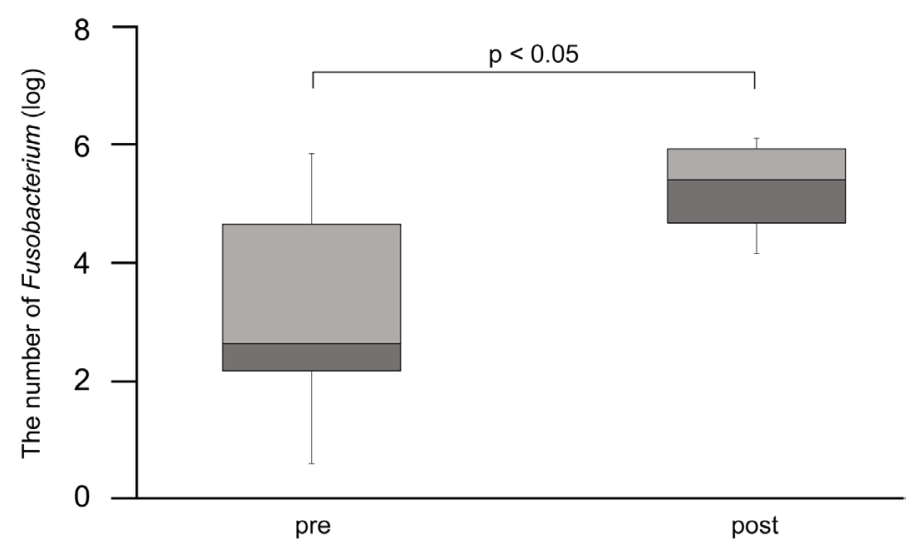

Fig. 4. Results of real-time PCR performed to detect the proportion of Fusobacterium. The post-FMT proportion of Fusobacterium was significantly increased $(\mathrm{p}<0.05)$.

Table 2. Oligonucleotide primers/probes used in this study

\begin{tabular}{ccccc}
\hline Target & Primer & & Annealing & Reference \\
\hline Fusobacterium & Fuso-F & KGG GCT CAA CMC MGT ATT GCGT & $51^{\circ} \mathrm{C} 30 \mathrm{sec}$ & {$[29,30]$} \\
& Fuso-R & TCG CGT TAG CTT GGG CGC TG & & \\
\hline
\end{tabular}

pre-FMT number $(\mathrm{p}<0.05)$. However, in two dogs with IBD, the pre-FMT number of Fusobacterium was similar to that in donor dogs.

\section{DISCUSSION}

In this study, we performed FMT in nine dogs with IBD and then investigated the changes in clinical signs and fecal microbiome. The CIBDAI score significantly decreased in all dogs, indicating improvements in clinical signs. Additionally, a lack of adverse effects during FMT demonstrated its safety. Thus, FMT could be an effective and safe treatment for canine IBD.

The fecal microbiome was investigated in three dogs by 16S rRNA sequencing. Notably, the pre-FMT proportion of Fusobacteria was lower in the dogs with IBD than in the donor dogs, whereas the post-FMT proportion in dogs with IBD was significantly higher.

Fusobacterium was detected by qPCR in all nine dogs. The post-FMT number of Fusobacterium was significantly increased $(p<0.05)$, which was consistent with the results of 16S rRNA sequence analysis. This suggests that a low proportion of Fusobacterium is a characteristic feature of canine IBD and that Fusobacterium is involved in this disease.

Fusobacterium is a butyric acid-producing bacterium. Butyric acid is used as a major energy source by epithelial cells in the mucous membrane of the large intestine; it inhibits the growth of colorectal cancer cells and induces differentiation and apoptosis of them [31-35]. Butyric acid promotes the maturation of acquired immune system cells that play a central role in suppressing inflammation and allergic reactions [36, 37]. It also inhibits the production of inflammatory cytokines [38].

Butyrate suppressed the onset of colorectal cancer in a model animal $[39,40]$. Additionally, some studies have reported that butyric acid improves the symptoms of bowel-related diseases and that the butyric acid concentration is lower in the feces of patients with ulcerative colitis [41-43]. Therefore, butyric acid is considered important for maintaining large intestine function and for preventing and improving large intestine-related diseases.

However, several studies have reported that Fusobacterium is a pro-inflammatory pathogen $[25,44-46]$, with a high abundance in patients with IBD and mouse models of IBD $[25,46]$. Other studies have concluded that Fusobacterium nucleatum may promote colonic neoplasia development by downregulating antitumor T-cell-mediated adaptive immunity [47]. Although Fusobacterium may be a risk factor for colorectal carcinoma in mice and humans [45-47], a low proportion of Fusobacterium may be specific to canine IBD.

In this study, FMT was used to effectively treat canine IBD. The proportion of Fusobacterium is higher in the gut microbiome of the canine or has been reported to be higher in the gut microbiome of the canine than in the microbiome of other animals, including mouse models and humans [25, 44-47]. Species differences may exist in the gut microbiome, which is affected by various factors, including diet, habitat, and gastrointestinal anatomical differences.

Here, the proportion of Fusobacterium tended to be low in dogs with IBD, although two dogs $(22 \%)$ showed normal proportions of Fusobacterium. However, Fusobacterium may be associated with canine IBD. Further studies are needed to investigate the effect of Fusobacterium on FMT for canine IBD, because the proportion of Fusobacterium was increased by FMT, even in the two dogs that showed normal proportions.

Future studies should examine the differences in the proportion of Fusobacterium in dogs with IBD. It should also be noted that we did not perform endoscopy on the dogs after FMT due to a lack of consent from the owners. Therefore, we were unable to confirm any changes in the intestinal mucosa resulting from FMT. Therefore, it is necessary to identify a marker indicating 
pathologic improvements.

Although there are individual differences in dogs with IBD, FMT needs to be repeated at a frequency of once every 2-3 weeks in many cases. A long-term investigation in a larger number of cases will be necessary in the future to determine the interval for FMT.

In conclusion, we showed that FMT should be considered a novel treatment option for canine IBD or intractable IBD in the future.

\section{CONFLICT OF INTEREST}

No potential conflicts of interest were reported by the authors.

\section{ACKNOWLEDGMENT}

We would like to thank Editage (www.editage.com) for English language editing.

\section{REFERENCES}

1. Mukherjee S, Joardar N, Sengupta S, Sinha Babu SP. 2018. Gut microbes as future therapeutics in treating inflammatory and infectious diseases: lessons from recent findings. J Nutr Biochem 61: 111-128. [Medline] [CrossRef]

2. Chaitman J, Jergens AE, Gaschen F, Garcia-Mazcorro JF, Marks SL, MarroquinCardona AG, Richter K, Rossi G, Suchodolski JS, Weese JS. 2016. Commentary on key aspects of fecal microbiota transplantation in small animal practice. Vet Med (Auckl) 7: 71-74. [Medline]

3. Borody TJ, Khoruts A. 2011. Fecal microbiota transplantation and emerging applications. Nat Rev Gastroenterol Hepatol 9: 88-96. [Medline] [CrossRef]

4. Kelly BJ, Tebas P. 2018. Clinical practice and infrastructure review of faecal microbiota transplantation for Clostridium difficile infection. Chest 153: 266-277. [Medline] [CrossRef]

5. van Nood E, Vrieze A, Nieuwdorp M, Fuentes S, Zoetendal EG, de Vos WM, Visser CE, Kuijper EJ, Bartelsman JF, Tijssen JG, Speelman P, Dijkgraaf MG, Keller JJ. 2013. Duodenal infusion of donor feces for recurrent Clostridium difficile. N Engl J Med 368: 407-415. [Medline] [CrossRef]

6. Kelly CR, Kahn S, Kashyap P, Laine L, Rubin D, Atreja A, Moore T, Wu G. 2015. Update on fecal microbiota transplantation 2015: indications, methodologies, mechanisms, and outlook. Gastroenterology 149: 223-237. [Medline] [CrossRef]

7. Cammarota G, Masucci L, Ianiro G, Bibbò S, Dinoi G, Costamagna G, Sanguinetti M, Gasbarrini A. 2015. Randomised clinical trial: faecal microbiota transplantation by colonoscopy vs. vancomycin for the treatment of recurrent Clostridium difficile infection. Aliment Pharmacol Ther 41: 835-843. [Medline] [CrossRef]

8. Kassam Z, Lee CH, Yuan Y, Hunt RH. 2013. Fecal microbiota transplantation for Clostridium difficile infection: systematic review and meta-analysis. Am J Gastroenterol 108: 500-508. [Medline] [CrossRef]

9. Cammarota G, Ianiro G, Gasbarrini A. 2014. Fecal microbiota transplantation for the treatment of Clostridium difficile infection: a systematic review. J Clin Gastroenterol 48: 693-702. [Medline] [CrossRef]

10. Eiseman B, Silen W, Bascom GS, Kauvar AJ. 1958. Fecal enema as an adjunct in the treatment of pseudomembranous enterocolitis. Surgery 44: 854-859. [Medline]

11. Rossen NG, MacDonald JK, de Vries EM, D'Haens GR, de Vos WM, Zoetendal EG, Ponsioen CY. 2015. Fecal microbiota transplantation as novel therapy in gastroenterology: a systematic review. World J Gastroenterol 21: 5359-5371. [Medline] [CrossRef]

12. Borody TJ, George L, Andrews P, Brandl S, Noonan S, Cole P, Hyland L, Morgan A, Maysey J, Moore-Jones D. 1989. Bowel-flora alteration: a potential cure for inflammatory bowel disease and irritable bowel syndrome? Med J Aust 150: 604. [Medline] [CrossRef]

13. Suskind DL, Brittnacher MJ, Wahbeh G, Shaffer ML, Hayden HS, Qin X, Singh N, Damman CJ, Hager KR, Nielson H, Miller SI. 2015. Fecal microbial transplant effect on clinical outcomes and fecal microbiome in active Crohn's disease. Inflamm Bowel Dis 21: 556-563. [Medline] [CrossRef]

14. Cui B, Feng Q, Wang H, Wang M, Peng Z, Li P, Huang G, Liu Z, Wu P, Fan Z, Ji G, Wang X, Wu K, Fan D, Zhang F. 2015. Fecal microbiota transplantation through mid-gut for refractory Crohn's disease: safety, feasibility, and efficacy trial results. J Gastroenterol Hepatol 30: 51-58. [Medline] [CrossRef]

15. Bennet JD, Brinkman M. 1989. Treatment of ulcerative colitis by implantation of normal colonic flora. Lancet 1: 164. [Medline] [CrossRef]

16. Moayyedi P, Surette MG, Kim PT, Libertucci J, Wolfe M, Onischi C, Armstrong D,
Marshall JK, Kassam Z, Reinisch W, Lee CH. 2015. Fecal microbiota transplantation induces remission in patients with active ulcerative colitis in a randomized controlled trial. Gastroenterology 149: 102-109.e6. [Medline] [CrossRef]

17. Rossen NG, Fuentes S, van der Spek MJ, Tijssen JG, Hartman JH, Duflou A, Löwenberg M, van den Brink GR, Mathus-Vliegen EM, de Vos WM, Zoetendal EG, D'Haens GR, Ponsioen CY. 2015. Findings from a randomized controlled trial of fecal transplantation for patients with ulcerative colitis. Gastroenterology 149: 110-118.e4. [Medline] [CrossRef]

18. Paramsothy S, Kamm MA, Kaakoush NO, Walsh AJ, van den Bogaerde J, Samuel D, Leong RWL, Connor S, Ng W, Paramsothy R, Xuan W, Lin E, Mitchell HM, Borody TJ. 2017. Multidonor intensive faecal microbiota transplantation for active ulcerative colitis: a randomised placebo-controlled trial. Lancet 389: 1218-1228. [Medline] [CrossRef]

19. Simrén M, Barbara G, Flint HJ, Spiegel BM, Spiller RC, Vanner S, Verdu EF, Whorwell PJ, Zoetendal EG, Rome Foundation Committee 2013. Intestinal microbiota in functional bowel disorders: a Rome foundation report. Gut 62: 159-176. [Medline] [CrossRef]

20. Pinn DM, Aroniadis OC, Brandt LJ. 2015. Is fecal microbiota transplantation (FMT) an effective treatment for patients with functional gastrointestinal disorders (FGID)? Neurogastroenterol Motil 27: 19-29. [Medline] [CrossRef]

21. Johnsen PH, Hilpüsch F, Cavanagh JP, Leikanger IS, Kolstad C, Valle PC, Goll R. 2018. Faecal microbiota transplantation versus placebo for moderate-to-severe irritable bowel syndrome: a double-blind, randomised, placebo-controlled, parallel-group, single-centre trial. Lancet Gastroenterol Hepatol 3: 17-24. [Medline] [CrossRef]

22. Suchodolski JS, Dowd SE, Wilke V, Steiner JM, Jergens AE. 2012. 16S rRNA gene pyrosequencing reveals bacterial dysbiosis in the duodenum of dogs with idiopathic inflammatory bowel disease. PLoS One 7: e39333. [Medline] [CrossRef]

23. Suchodolski JS, Morris EK, Allenspach K, Jergens AE, Harmoinen JA, Westermarck E, Steiner JM. 2008. Prevalence and identification of fungal DNA in the small intestine of healthy dogs and dogs with chronic enteropathies. Vet Microbiol 132: 379-388. [Medline] [CrossRef]

24. Simpson KW, Jergens AE. 2011. Pitfalls and progress in the diagnosis and management of canine inflammatory bowel disease. Vet Clin North Am Small Anim Pract 41 381-398. [Medline] [CrossRef]

25. Niina A, Kibe R, Suzuki R, Yuchi Y, Teshima T, Matsumoto H, Kataoka Y, Koyama H. 2019. Improvement in clinical symptoms and fecal microbiome after fecal microbiota transplantation in a dog with inflammatory bowel disease. Vet Med (Auckl) 10: 197-201. [Medline]

26. Haas E, Rütgen BC, Gerner W, Richter B, Tichy A, Galler A, Bilek A, Thalhammer JG, Saalmüller A, Luckschander-Zeller N. 2014. Phenotypic characterization of canine intestinal intraepithelial lymphocytes in dogs with inflammatory bowel disease. J Vet Intern Med 28: 1708-1715. [Medline] [CrossRef]

27. Jergens AE, Schreiner CA, Frank DE, Niyo Y, Ahrens FE, Eckersall PD, Benson TJ, Evans R. 2003. A scoring index for disease activity in canine inflammatory bowel disease. J Vet Intern Med 17: 291-297. [Medline] [CrossRef]

28. Suchodolski JS, Markel ME, Garcia-Mazcorro JF, Unterer S, Heilmann RM, Dowd SE, Kachroo P, Ivanov I, Minamoto Y, Dillman EM, Steiner JM, Cook AK, Toresson L. 2012. The fecal microbiome in dogs with acute diarrhea and idiopathic inflammatory bowel disease. PLoS One 7: e51907. [Medline] [CrossRef]

29. Minamoto Y, Dhanani N, Markel ME, Steiner JM, Suchodolski JS. 2014. Prevalence of Clostridium perfringens, Clostridium perfringens enterotoxin and dysbiosis in fecal samples of dogs with diarrhea. Vet Microbiol 174: 463-473. [Medline] [CrossRef]

30. Ziese AL, Suchodolski JS, Hartmann K, Busch K, Anderson A, Sarwar F, Sindern N, Unterer S. 2018. Effect of probiotic treatment on the clinical course, intestinal microbiome, and toxigenic Clostridium perfringens in dogs with acute hemorrhagic diarrhea. PLoS One 13: e0204691. [Medline] [CrossRef]

31. Hamer HM, Jonkers D, Venema K, Vanhoutvin S, Troost FJ, Brummer RJ. 2008 Review article: the role of butyrate on colonic function. Aliment Pharmacol Ther 27: 104-119. [Medline] [CrossRef]

32. Scheppach W, Weiler F. 2004. The butyrate story: old wine in new bottles? Curr Opin Clin Nutr Metab Care 7: 563-567. [Medline] [CrossRef]

33. Archer SY, Meng S, Shei A, Hodin RA. 1998. p21(WAF1) is required for butyratemediated growth inhibition of human colon cancer cells. Proc Natl Acad Sci USA 95: 6791-6796. [Medline] [CrossRef]

34. Chopin V, Toillon RA, Jouy N, Le Bourhis X. 2002. Sodium butyrate induces P53independent, Fas-mediated apoptosis in MCF-7 human breast cancer cells. Br J Pharmacol 135: 79-86. [Medline] [CrossRef]

35. Velcich A, Palumbo L, Jarry A, Laboisse C, Racevskis J, Augenlicht L. 1995. Patterns of expression of lineage-specific markers during the in vitro-induced differentiation of HT29 colon carcinoma cells. Cell Growth Differ 6: 749-757. [Medline]

36. Arpaia N, Campbell C, Fan X, Dikiy S, van der Veeken J, deRoos P, Liu H, Cross JR, Pfeffer K, Coffer PJ, Rudensky AY. 2013. Metabolites produced by commensal bacteria promote peripheral regulatory T-cell generation. Nature 504: 451-455. [Medline] [CrossRef]

37. Furusawa Y, Obata Y, Fukuda S, Endo TA, Nakato G, Takahashi D, Nakanishi Y, Uetake C, Kato K, Kato T, Takahashi M, Fukuda NN, Murakami S, Miyauchi E, Hino S, Atarashi K, Onawa S, Fujimura Y, Lockett T, Clarke JM, Topping DL, Tomita M, 
Hori S, Ohara O, Morita T, Koseki H, Kikuchi J, Honda K, Hase K, Ohno H. 2013. Commensal microbe-derived butyrate induces the differentiation of colonic regulatory T cells. Nature 504: 446-450. [Medline] [CrossRef]

38. Chang PV, Hao L, Offermanns S, Medzhitov R. 2014. The microbial metabolite butyrate regulates intestinal macrophage function via histone deacetylase inhibition. Proc Natl Acad Sci USA 111: 2247-2252. [Medline] [CrossRef]

39. D'Argenio G, Cosenza V, Delle Cave M, Iovino P, Delle Valle N, Lombardi G, Mazzacca G. 1996. Butyrate enemas in experimental colitis and protection against large bowel cancer in a rat model. Gastroenterology 110: 1727-1734. [Medline] [CrossRef]

40. Medina V, Afonso JJ, Alvarez-Arguelles H, Hernández C, González F. 1998. Sodium butyrate inhibits carcinoma development in a 1,2-dimethylhydrazine-induced rat colon cancer. JPEN J Parenter Enteral Nutr 22: 14-17. [Medline] [CrossRef]

41. Vernia P, Caprilli R, Latella G, Barbetti F, Magliocca FM, Cittadini M. 1988. Fecal lactate and ulcerative colitis. Gastroenterology 95: 1564-1568. [Medline] [CrossRef]

42. Scheppach W, Sommer H, Kirchner T, Paganelli GM, Bartram P, Christl S, Richter F, Dusel G, Kasper H. 1992. Effect of butyrate enemas on the colonic mucosa in distal ulcerative colitis. Gastroenterology 103: 51-56. [Medline] [CrossRef]

43. Vernia P, Annese V, Bresci G, d'Albasio G, D'Incà R, Giaccari S, Ingrosso M, Mansi
C, Riegler G, Valpiani D, Caprilli R, Gruppo Italiano per lo Studio del Colon and del Retto 2003. Topical butyrate improves efficacy of 5-ASA in refractory distal ulcerative colitis: results of a multicentre trial. Eur J Clin Invest 33: 244-248. [Medline] [CrossRef]

44. McCoy AN, Araújo-Pérez F, Azcárate-Peril A, Yeh JJ, Sandler RS, Keku TO. 2013. Fusobacterium is associated with colorectal adenomas. PLoS One 8: e53653. [Medline] [CrossRef]

45. Dharmani P, Strauss J, Ambrose C, Allen-Vercoe E, Chadee K. 2011. Fusobacterium nucleatum infection of colonic cells stimulates MUC2 mucin and tumor necrosis factor alpha. Infect Immun 79: 2597-2607. [Medline] [CrossRef]

46. Castellarin M, Warren RL, Freeman JD, Dreolini L, Krzywinski M, Strauss J, Barnes R, Watson P, Allen-Vercoe E, Moore RA, Holt RA. 2012. Fusobacterium nucleatum infection is prevalent in human colorectal carcinoma. Genome Res 22: 299-306. [Medline] [CrossRef]

47. Mima K, Sukawa Y, Nishihara R, Qian ZR, Yamauchi M, Inamura K, Kim SA, Masuda A, Nowak JA, Nosho K, Kostic AD, Giannakis M, Watanabe H, Bullman S, Milner DA, Harris CC, Giovannucci E, Garraway LA, Freeman GJ, Dranoff G, Chan AT, Garrett WS, Huttenhower C, Fuchs CS, Ogino S. 2015. Fusobacterium nucleatum and $\mathrm{T}$ cells in colorectal carcinoma. JAMA Oncol 1: 653-661. [Medline] [CrossRef] 